\title{
Typology of Rural Territories of the Russian Federation Subjects
}

\author{
Svetlana S. Mikhaylova \\ Medegma Ts. Budazhanayeva
}

East Siberia State University of Technology and Management, Ulan-Ude, Russia

Email: medegma_@mail.ru

Tatyana V. Sarycheva

Lyudmila P. Bakumenko

Mari State University, Yoshkar-Ola, Russia

Email: tvdolmatova@bk.ru

Doi:10.5901/mjss.2015.v6n3s7p205

\section{Abstract}

The article is devoted to the methodological approaches of the complex typology of the Russian Federation rural areas for the purposes of regional governance. The proposed method takes into account the differences in rural areas of the region in terms of socio-economic development, the economic potential and limitations of its use, based on the application of multivariate statistical analysis of integrated indicators. It summarizes the main problems of socio-economic development of the Russian Federation rural areas, one of the reasons, which, according to the authors, is an insufficient account of the special areas in the implementation of rural development policies at both the Federal and regional levels of government. Here it is suggested a hierarchical system of indicators which is used to develop a typology of regional rural areas, including aggregated typology criteria: the level of economic potential, the level of restrictions of the use of the economic potential, the level of social and economic development, as well as integrated and private figures. It is performed the approbation of the methodology with the use of data from rural municipal districts of the agricultural subject of the Russian Federation - the Republic of Buryatia. The obtained typology of rural areas allowed us to justify a differentiated approach to the management of socio-economic development of the regional rural areas. The results of the study can be recommended to the federal and regional authorities in improving the management of rural development based on a differentiated approach.

Keywords: rural areas, spatial inequality, rural typology, typological criteria, subject of the Russian Federation.

\section{Introduction}

Rural areas have traditionally played an important role in socio-economic development of Russia. During the transition period, the contribution of the village in the economy declined significantly due to the widespread reduction of agricultural production and the related economic activities. All this has led to a decrease in the standard of living of the rural population, population decline, and escalation of social problems in rural areas. Currently, a quarter of the Russian population continues to live in rural areas. In some regions the share of the rural population is more than $50 \%$, including in some subjects of the Southern, North Caucasus and Siberian Federal regions. Socio-economic development of these regions is due, primarily, to the efficiency of management of rural development, which is implemented at both the Federal and regional levels.

The main indicator of the socio-economic well-being is the number of rural population and population dynamics. In 2013, the total population of the Russian Federation was 143,51 million people, in rural areas 37,17 million people lived. Between 1990 and 2013, the total population decreased by 4,46 million people, including the rural population by 1,72 million people. Since 2009 there has been a positive dynamics of the total population, at the same time, there is the trend of the absolute number reduction of the rural population. So in 2010 the rural population decreased by 188,75 thousand people, in 2011 - by 228,86 thousand people, in 2012 - by 107,69 thousand people, in 2013 - by 98,09 thousand people.

The decline in the share of rural population is a consequence, of the one hand, the process of urbanization, on the other hand, the degradation of rural areas. This fact is confirmed by results of all-Russia population census of 2002 and 2010. In 2010 the total number of rural settlements in the Russian Federation was 153 124, which is below the level of 
2002 by 2165 settlements. The share of rural settlements, which at the time of the census the population was not living, grew from $8,43 \%$ to $12,68 \%$. Thus, the development of rural areas of the Russian Federation is connected with the extensive depopulation of the rural population and socio-economic degradation of the entire rural space. The development management of rural territories in the Russian Federation is based on industry models, considering the countryside in the first place, as the location of resources of agro-industrial complex. Because of the significant territorial differences, the non-comparability of the natural conditions of agricultural production, this management model leads to the deepening of socio-economic inequalities in the country and a specific region.

Currently, the Russian Government adopted the Strategy for the sustainable development of rural areas of the Russian Federation for the period until 2030, which provides for a differentiated approach to rural development, according to each type of regions differs in terms of the nature and development of rural areas, proposed a set of priority measures. At the same time it has not been sufficiently considered the implementation of the differentiated approach and determines the differences in the development of rural areas on the level of a specific region. In accordance with the above we set a goal to develop the typology of rural areas of the Russian Federation, providing for the formation of the hierarchical system of indicators, including typological criteria, integral and benchmarks.

\section{Methodological Framework}

The current legislation of the Russian Federation does not specify the quantitative criteria for classifying territorial units to rural areas, delimitation of rural and urban settlements. In the Federal target program "Sustainable development of rural areas for 2014-2017 and for the period till 2020" under the rural areas (countryside) it is meant a rural settlement or rural settlements and inter-settlement territory, united by a common territory, a municipal district and rural settlements and towns included in the urban districts (excluding urban districts, which are administrative centers of subjects of the Russian Federation) and urban settlements on the territory of which dominant activities are related to the production and processing of agricultural products.

There are rural areas with low and high density of rural population. Article 11 of the Federal law "On General principles of organization of local self-government in the Russian Federation" determines that the territories with low density of the rural population are areas with rural population density more than three times lower than the average rural population density in the Russian Federation; to the areas with high density of rural population are areas with rural population density more than three times higher than the average density of the rural population in the Russian Federation. In accordance with the provisions of the above-mentioned federal law in areas with low-density rural areas and in remote areas there may be the elimination of settlements with a population of more than 100 people. Thus, in the Russian Federation the main normative criterion for the classification of the rural areas is the predominance of agricultural activities, an additional criterion is the population.

The Russian economic science also received common approach to the definition of "rural area", based on the opposition of the characteristics and conditions of the development of urban and rural areas, including in the provision of the infrastructure, development of services, the degree of diversification of the economy (Klikich, \& Petrova, 2009).

In international practice, the basis of allocation of rural areas are indicators of strength, density, structure of employment, the level of urbanization of the territory, and also takes into account the distance factor (periphery) of centers of economic development (Mantino, 2010).

Use of international classifications in relation to the Russian rural areas leads to biased results due to the incompatibility of basic typological features: low density of population of the Russian Federation, the geographical remoteness of cities and rural settlements. So it is necessary to develop self-classification of rural areas of the Russian Federation.

As part of the development of the Concept of sustainable development of rural areas by a team of researchers, a typology of subjects of the Russian Federation on the nature and conditions of rural development is proposed. According to the developers of the typology, the main factors determining the development of rural areas are: natural conditions, socio-demographic potential, the degree of development of transport and energy infrastructure and geographical position. Typological groups of regions of the Russian Federation are different by level and character development, agricultural use, capabilities and limitations of rural development. The proposed typology examines regional differences in the level and conditions of development of rural areas and is not applicable at the subregional level. The authors of the typology recommend selecting inside of the region: the relatively developed areas, depressed areas, and rural areas transitional type.

It should be noted that current legislation does not involve differentiation of measures of state support of agroindustrial complex and rural territories based on belonging to a particular type. The need to account for differences in 
rural areas, including in terms of the development of agricultural production, is contained by provisions of Article 7 of the Federal Law "On agricultural development", which provides for the need of the state support of agricultural producers operating in unfavorable for agriculture areas. Unfavorable for agricultural production areas recognized territory, which due to climatic conditions, soil conditions, as well as socio-economic factors, the level of income of agricultural producers is lower than the average in agriculture, but agricultural production should be to provide rural employment, increase the level of income, preservation of local traditions. One of the criteria for classifying adverse territory for the production of agricultural products is the level of socio-economic development of rural areas in the region. It is evaluated the developed integral index, which takes into account the growth rate of the rural population over the past 5 years, the ratio of average per capita disposable resources of rural households to the regional minimum wage, the unemployment rate in rural areas, calculated by the ILO (International Labor Organization) .

Thus, in the Russian practice it develops understanding about the need for the flexible approach to the management of socio-economic development of rural areas, recognition of the inadequacy of measures to support the agro-industrial complex to provide equal opportunities for the development of the entire rural space. Further development of research in the area of differentiation of rural areas involves the development of a comprehensive typology of rural areas at the level of the specific subject of the Russian Federation.

The authors proposed a methodological approach to the development of a typology of rural areas in the region with groups of typological criteria: the level of economic potential, the level of restrictions on the use of the economic potential, the level of socio-economic development. Decisive impact on the socio-economic development of rural areas is the presence and the structural balance of economic resources, together forming the economic potential of the territory. As part of the economic potential of rural areas there should be distinguished: natural resource, manufacturing, financial, human resources and innovation. Natural resources are objectively existing factor of economic development; define the economic specialization, the population of the territory. Production resources are the main element in determining the level and dynamics of economic development of the territory. The elements of the economic potential that are mobile include: labor, financial and innovative resources. To attract them you need to create some favorable socio-economic, institutional conditions on the territory. The authors highlighted the limitations of socio-economic development of rural areas: administrative, infrastructural, socio-cultural and environmental constraints. Administrative limitations lie in the imperfection of the legal regulation of economic activity, the presence of administrative barriers, and low level of organization of local self-government. One of the main conditions of the private investment in the development of the area is the availability of basic infrastructure such as roads, utilities, communication. In their absence or low level of attractiveness of the area as an investment object is reduced, and the cost of operating business entities increased. Socio-cultural limitations should include low susceptibility of the rural population to new technologies, customs and traditions that restrict the use of any resource, engagement in any activities. The natural limitation of economic activity in the territory is its ecological and resource capacity (Lessmann, 2014).

In accordance with the administrative-territorial entities of the Russian Federation, the organization of regional and municipal statistics is rural municipal districts.

For a quantitative assessment of typological criteria, the authors propose a system of indicators (table 1).

Table 1. The system of indicators characterizing the typology criteria of rural areas in the region

\begin{tabular}{|c|c|c|}
\hline Criteria & Integral indicators & Indicators \\
\hline \multirow[t]{5}{*}{ The level of economic potential } & Natural-resource potential & $\begin{array}{l}\text { Arable land per capita, hectare } \\
\text { The average yield of sown areas (over } 5 \text { years), ton for } 1 \text { hectare } \\
\text { The volume of cutting without harming the environment, thousand cubic } \\
\text { meters per capita } \\
\text { Timber harvesting, thousand cubic meters per capita }\end{array}$ \\
\hline & Production potential & $\begin{array}{l}\text { The cost of fixed assets per capita, thousand rubles } \\
\text { Capital productivity, roubles }\end{array}$ \\
\hline & Financial potential & $\begin{array}{l}\text { Local budget revenues per capita, thousand rubles } \\
\text { Own revenues of the budget per capita, thousand rubles } \\
\text { The volume of investments per capita, thousand rubles } \\
\text { Payroll per capita, thousand rubles }\end{array}$ \\
\hline & Labor potential & $\begin{array}{l}\text { The share of working-age population, } \% \\
\text { The level of economic activity of population, } \% \\
\text { The natural increase of population, } \%\end{array}$ \\
\hline & Innovation potential & $\begin{array}{l}\text { The number of innovative organizations per } 1000 \text { people. } \\
\text { The volume of innovative products per capita, thous. rubles } \\
\text { Expenditures of organizations on innovation, per capita, thous. rubles }\end{array}$ \\
\hline
\end{tabular}




\begin{tabular}{|c|c|c|}
\hline \multirow[t]{4}{*}{$\begin{array}{l}\text { The level restriction use of } \\
\text { economic potential }\end{array}$} & Infrastructure limitations & $\begin{array}{l}\text { The density of roads, km of roads per } 1000 \mathrm{sq} \mathrm{km.} \\
\text { The proportion of old and dilapidated housing stock, } \%\end{array}$ \\
\hline & Environmental limitations & $\begin{array}{l}\text { The proportion of areas with special environmental conditions, } \% \\
\text { The amount of pollutants per } 1 \mathrm{sq} . \mathrm{km} \text {, ton }\end{array}$ \\
\hline & Administrative limitations & $\begin{array}{l}\text { Financial dependence of the local budget, } \% \\
\text { The share of budget expenditures formed in programs } \%\end{array}$ \\
\hline & Socio-cultural limitations & $\begin{array}{l}\text { The crime rate, per } 1000 \text { people. } \\
\text { Sickness rate per } 10000 \text { people. } \\
\text { The level of disability, per 1,000 people }\end{array}$ \\
\hline \multicolumn{2}{|c|}{ The level of socio-economic development } & $\begin{array}{l}\text { The volume of own production per capita, thous. roubles } \\
\text { Agricultural output per capita, thous. roubles } \\
\text { The number of businesses per } 10000 \text { people, } \\
\text { Retail trade turnover per capita, thous. roubles } \\
\text { Housing, sq.m. per capita } \\
\text { The overall mortality rate, \%o }\end{array}$ \\
\hline
\end{tabular}

The structure of the indicators characterizing the typological criteria and integrated indicators is determined by analyzing the variability of their value in the context of the territories. Baseline characteristics are shown in comparable form. The criteria are the result of the aggregation formula arithmetic mean of integrated indicators developed using principal component analysis. Integrated indicators are presented to the 100-point scale according to the formula:

$$
R_{i j}=\left(r_{i j}-r_{j}^{\min }\right) /\left(r_{j}^{\max }-r_{j}^{\min }\right) \times 100,
$$

where $R_{i j}$ integral index ranges from 0 to $100 ; r_{i j}$ - principal component; ${ }^{r_{j}^{\max }}$ - maximum value; ${ }^{r_{j}^{\min }}$ - minimum value; $i$ - number of area, $i=1,2, \ldots n ; j$ - number of component, $j=1,2, \ldots m$.

Implementation of the proposed method allows to develop a comprehensive typology of rural areas of the subject of the Russian Federation, taking into account the current level of economic and social development, the availability of economic resources and limit their use, which will serve as the basis for the implementation of a differentiated approach to the rural development management.

\section{Results}

The problem of socio-economic development of rural areas of the Russian Federation has a pronounced regional specifics in connection features of the spatial distribution of the rural population and rural economy. The subjects of the Russian Federation are characterized by incomparable climatic conditions, geographic location, differences in infrastructure provision and, consequently, the problem of rural development have territorial characteristics, which requires the formation of a regional level of government rural development (Ilchenko, Sarycheva, \& Sevastyanova, 2012)

The problem of rural development is the most relevant to the region, a large part of the population lives in rural area. The proportion of the rural population in the total population is over $50 \%$ in seven subjects of the Russian Federation, from 30 to 50\% - in 31 subjects of the Russian Federation, from 10 to $30 \%$ - in 40 regions of Russia, 10\% - in 5 regions of Russia.

The most urbanized areas are St. Petersburg (the proportion of the rural population is $0,0 \%)$, Moscow $(1,1 \%)$, the Magadan region (4,7 per cent), Murmansk region (7,3 per cent), Khanty-Mansiysk Autonomous Okrug - Ugra (8,0\%). More than half of the population lives in rural areas in the Altai Republic (71,0\%), the Chechen Republic $(65,2 \%)$, the Republic of Ingushetia (59,6\%), the Karachay-Cherkess Republic (57,3 per cent), the Republic of Kalmykia (55,1 per cent), the Republic of Adygea (53,0\%). These regions have not developed the preconditions for urbanization of the population, have not developed the large industrial centers, pulling together the working-age population. Stimulating government policies aimed at accelerating infrastructure development is carried out in these regions (Khokhlova, \& Budazhanaeva, 2010).

The second group, in which the proportion of the rural population in the total population is $30-50 \%$, includes the regions with predominantly agrarian specialization. The main reason is the high level of competition and limited access to markets of manufactured products. In this group the Republic of Buryatia comes in, in which the share of rural population in total population was $41,1 \%$ in 2013. In the region there are special conditions of management as it is a part of the Baikal natural territory. The region is characterized by a low level of socio-economic development, the level of GDP per capita occupies the 65th place among the subjects of the Russian Federation. Poor dynamics of the traditional economic activities of the region increases lag as the base index of physical volume of gross regional product of the Republic of Buryatia in the period of 2004-2012 amounted to 125,8\%, the index value for all subjects of the Russian Federation 
amounted to $140,1 \%$. The Republic of Buryatia has a unique natural resource potential, its development is associated with a number of difficulties, including a lack of appropriate infrastructure, difficult terrain area, and environmental constraints. There is an outflow of labor from the region; the main causes of it are the low level of wages in the economy, job cuts in basic economic activities, insufficient number of new jobs created in developing economic activities. The Republic of Buryatia is one of the less developed regions which are not capable of economic restructuring from its own financial resources with low attractiveness for private investors.

Spatial analysis showed that the region is characterized by growing social and economic differentiation of rural areas; there are areas of high, medium and low levels of socio-economic development. There are big differences in the level of budgetary security of municipal rural areas. The situation in regional socio-economic environment of most rural areas is not subject to change over the past five years, while there are areas, the position of which relative to the totality of deteriorates. The main reason of the destabilization of the socio-economic situation in rural areas in the region is a critical condition of agricultural production, poor diversification of the local economy (Budazhanaeva, 2014).

For the typology of rural areas in the Republic of Buryatia, it is formed an information base on the indicators presented in the table. 1. The baselines, using principal component analysis, aggregated in the criteria, then the basis of the criteria in the procedure implemented clustering, will highlight 4 groups of rural areas in the region: "developed", "promising", "the territory with high restrictions", "underdeveloped". The typological structure of the groups and the values of typological criteria are presented in table 2.

Table 2. The results of rural areas typology in the region

\begin{tabular}{|l|c|c|c|}
\hline \multirow{2}{*}{ Type } & \multicolumn{3}{|c|}{ The values of the criteria } \\
\cline { 2 - 4 } & $\begin{array}{c}\text { The level of } \\
\text { economic potential }\end{array}$ & $\begin{array}{c}\text { The level of restrictions on } \\
\text { the economic potential use }\end{array}$ & $\begin{array}{c}\text { The level of socio-economic } \\
\text { development }\end{array}$ \\
\hline $\begin{array}{l}\text { Type 1 "Developed": Mukhorshibircky, Selenginsky, } \\
\text { Kyakhtinsky, Ivolginsky, Kabansky, Zakamensky, Zaigraevsky }\end{array}$ & 28 & 29 & 29 \\
\hline Type 2 "Promising": Pribaikalskiy, Okinsky & 55 & 43 & 37 \\
\hline $\begin{array}{l}\text { Type 3 "The territory with high restrictions": Muyskiy, North- } \\
\text { Baikalsky, Bauntovsky Evenkiisky }\end{array}$ & 64 & 72 & 74 \\
\hline $\begin{array}{l}\text { Type 4 "Underdeveloped": Dzhidinsky, Tarbagatayskiy, } \\
\text { Bichursky, Kizhinginsky, Yeravninsky, Tunkinsky, Khorinsky, } \\
\text { Kurumkansky, Barguzinsky }\end{array}$ & 28 & 42 & 15 \\
\hline
\end{tabular}

Type 1 "Developed" form of rural municipal districts, located at short distance from the center of economic development of the region - the city of Ulan-Ude. Developed rural areas have low level of limitations on the use of the economic potential, the value of the corresponding integral evaluation was 29 points out of a possible 100. Municipal areas are characterized by high infrastructure provision, public transport options, including railway. In the areas there are large industrial and agricultural enterprises. The socio-economic development of the rural areas is associated with geographical location, high transport security, the creation and development of enterprises of economy-forming industries. The current socio-economic situation in municipal areas is characterized as average, special attention is required to the current social situation in connection with a high level of social limitations of the use of the economic potential.

Type 2 "Promising" consists of rural municipalities, on the territory of which the development of non-agricultural areas, including tourism and recreational activities is possible. Promising rural areas have a high economic potential level, an integrated assessment was 55 points. Rural areas are not comparable in terms of socio-economic development as a result of various transport accessibility, geographical location, and existing economic specialization. In general, the selected type of rural areas is favorable for investment activity (integrated assessment of the use and limitations of economic potential is 43 points out of a possible 100).

Type 3 "The territory with high restrictions" contains 3 rural municipal districts of the region. The main typological feature is the high level of limitations on the use of the economic potential: the harsh climatic conditions, patchy population of the territory due to the mining specialization. Evaluation of limitations on the use of the economic potential in areas with high restrictions was 72 points.

Type 4 "Underdeveloped" form small-sized rural areas with low economic potential and the socio-economic development (the integrated assessment of 15 points). The municipal economy is not developed; there is no pronounced economic specialization. The main limitation is the lack of economic development, high moral and physical deterioration of existing production facilities, poor basic infrastructure. There is a shortage of financial resources, the dependence of local budget from financial assistance from budgets of higher levels. These areas do not have their own resources to 
ensure economic and social development. The standard of living of the local population depends on the state of agricultural production.

\section{Discussions}

The methodological approaches to the typology of rural areas of the Russian Federation can be used by Federal and regional authorities in the development and implementation of a differentiated approach to the management of socioeconomic development of rural areas. The results of the methodological approaches approbation according to the data of the Republic of Buryatia, formulated conclusions and recommendations can be used in practical activities of the executive authorities and local self-government.

\section{Conclusions}

Rural areas are the subject of public administration in view of the characteristics of population distribution, development of high infrastructural constraints. The level of socio-economic development of rural areas is determined by the specific development of economic links in the territory, embeddedness in the region's economy. High intra-regional differentiation requires a flexible management of agricultural development aimed at its reduction through the creation of an economic basis for the population throughout the rural space.

The problem of socio-economic development of rural areas is the most relevant to the agricultural regions of the Russian Federation, including the Republic of Buryatia. Rural areas are characterized by the region's social and economic heterogeneity, have incomparable climatic, geographical conditions. Based on the study and indicator synthesis of socio-economic development, the level of economic potential and limits its use, the typology of rural areas of the Republic of Buryatia is developed, according to the results of which four types of rural areas are highlighted: "developed", "promising", "the territory with high restrictions", "underdeveloped".

The proposed methodological approaches to the typology of rural areas are universal, based on publicly available official statistics and indicators, can be used to develop an appropriate typology for all subjects of the Russian Federation.

\section{References}

Federal law of the Russian Federation "The development of agriculture". (2006). [Online] Available: http://www.consultant.ru

Federal law of the Russian Federation " General Principles of Local Self-Government in the Russian Federation". (2003). [Online] Available: http://www.consultant.ru

The Russian Federation Government decree "The State program of development of agriculture and regulation of markets of agricultural products, raw materials and food for 2013 - 2020". (2012). [Online] Available: http://www.consultant.ru

The Russian Federation Government decree "About the Federal target program "Sustainable development of rural areas for 2014-2017 and for the period till 2020". (2013). [Online] Available: http://www.consultant.ru

The Russian Federation Government order «Strategy for the sustainable development of rural areas of the Russian Federation for the period till 2030". (2015). [Online] Available: http://www.consultant.ru

The Russian Federation Government decree "The approval of rules for classifying areas as unfavourable for agricultural production areas". (2015). [Online] Available: http://www.consultant.ru.

Anderson, J. R. (2003). Risk in rural development: challenges for managers and policy makers. Agricultural Systems, 75, $161-197$.

Budazhanaeva, M. Ts. (2014). Socio-economic differentiation analysis of rural municipalities of the Republic of Buryatia. [Online] Available: http://www.science-education.ru/120-15756

Ilchenko, A., Sarycheva, T., Sevastyanova, E. (2012). Selective social support as inter regional inequality evening out instrument. Modern high technologies. Regional supplement, 3, 17-23.

Khokhlova, O. A., Budazhanaeva, M. Ts. (2010). Statistical evaluation of the economic development quality of Russian regions. Spatial Economics, 1(21), 133-146.

Klikich, L. M., Petrova, A. P. (2009). Rural areas of the Republic of Bashkortostan: typology and development models. Regional Economics: theory and practice, 22, 2-6.

Kovalenko, E. G. (2012). Problems and mechanisms of development of rural territories. [Online] Available: www.rae.ru/fs/?section=content\&op=show_article\&article_id=9999008

Krutikv, V. K., Fyodorova, O. V. (2011). The development of rural areas: innovation, diversification. Kaluga: Publishing house of Flagman.

Lessmann, C. (2014). Spatial inequality and development - Is there an inverted-U relationship? Journal of Development Economics, 106, 35-51.

Li, Y., Long, H., Liu, Y. (2015). Spatio-temporal pattern of China's rural development: A rurality index perspective. Journal of Rural Studies, 38, 12-26. 
Mantino, F. (2010). Rural development in Europe. [Online] Available: http://www.fao.org/docrep/013/i2001r/i2001r.pdf (November 2, 2014)

Merenkova, I. N. (2010). Sustainable rural development: theoretical and methodological aspects of the evaluation. Regional Economics: theory and practice, 25 (160), 55-61.

Merzlov, A. V., Sadykov, M. R., Chaika, V. P., Ovchintseva, L. A., Popova, O. A. (2012). Introduction to sustainable rural development: key concepts and theoretical foundations. [Online] Available: http://www.tempus-rudeco.ru/modules_files/M01_RU_MTAA.pdf

Mishchenko, I. V. (2012). Spatial aspects of sustainable development of rural territories. Vestnik of Tomsk State University, 3(19), 95102.

Rogovskaya, N.V. (2009). Typology of rural areas at the regional level. [Online] Available: http://www.timacad.ru/conf_news/section2/ Rogovskaya_ru.pdf Sepik, D. (2005).

The regional competitiveness: some notions. [Online] Available: http://www.recep.ru/files/documents/regional_competitiveness_ru.pdf

Van Eupen, M., Metzger, M.J., Pérez-Soba, M., Verburg, P.H., Van Doorn, A., Bunce, R.G.H. (2012). A rural typology for strategic European policies. Land Use Policy, 29-3, 473-482.

Zasada, I, Reutter, M., Piorr, F., Lefebvre, M., Paloma, S. G. (2015). Between capital investments and capacity buildingDevelopment and application of a conceptual framework towards a place-based rural development policy. Land Use Policy, 46, 178-188. 
